\title{
PROGRESIVITAS PERJANJIAN DAUD
}

\author{
Andri Harvijanto \\ Sekolah Tinggi Teologi Injili Indonesia - Palu \\ E-mail:gavra_palu@yahoo.co.id
}

\begin{abstract}
God's covenant with David is a core part of understanding God's plan for the development of the realization of the restoration of the state of Israel in the midst of the nation's deterioration. David became an ideal figure for kings in the eschatological period.

In the future the promise will be fulfilled, renewed and expanded. Through the prophet Nathan a promise was given to David (2 Samuel 7: 12-17). Furthermore, the continuation of the David covenant can be understood through God's plan for the development of the realization of the restoration of the state of Israel in the midst of the nation's deterioration. David became an ideal figure for kings in the eschatological period.
\end{abstract}

Keywords: God's covenant, eschatological, David.

\begin{abstract}
Abstrak
Perjanjian Allah dengan Daud merupakan bagian inti untuk memahami rencana Allah bagi perkembangan perwujudan pemulihan keadaan Israel di tengah-tengah keterpurukan bangsa. Daud menjadi figur yang ideal bagi raja di masa eskatologis..

Di masa yang akan datang janji itu dipenuhi, diperbaharui dan diperluas. Melalui nabi Natan janji diberikan kepada Daud (2 Samuel 7:12-17). Selanjutnya kesinambungan perjanjian Daud dapat dipahami melalui rencana Allah bagi perkembangan perwujudan pemulihan keadaan Israel di tengah-tengah keterpurukan bangsa. Daud menjadi figur yang ideal bagi raja di masa eskatologis.
\end{abstract}

Kata Kunci: Perjanjian Allah, eskatologis, Daud 


\section{PENDAHULUAN}

Ketika umat Tuhan membicarakan tentang perjanjian Allah dengan umat-Nya, maka itu berarti sebenarnya umat Tuhan sedang dibawa kepada suatu sejarah perjanjian antara Allah dengan bangsa Israel. ${ }^{1}$ Perjanjian itu bukan berarti terjadinya ikatan hukum tetapi lebih bernuansa adanya hubungan pribadi antara Allah dengan manusia (Kejadian 21:27).

G.M. Tucker dalam bukunya yang dikutip oleh Carl Reed mengatakan, "Perjanjian itu tidak sama dengan kontrak hukum: Sebuah kontrak adalah transaksi bisnis. Tetapi perjanjian adalah ikatan relasional, dengan tujuan supaya dua pihak terkait satu sama lain secara jangka panjang. $^{2}$

Hampir seluruh isi PL dalam setiap tingkatannya, perjanjian menjadi sarana untuk mengekspresikan suatu hubungan. Hubungan itu telah dimulai sejak penciptaan. Sehingga makna perjanjian tidak hanya ditanggapi dari segi penggunaan bahasa Ibrani (berit) saja.

Memang bentuk-bentuk penulisan PL bervariasi, tetapi dasar pemahamnnya tidaklah lepas dari sarana perjanjian yang menjembatani pemahaman. Dengan demikian perjanjian antara Allah dan manusia menolong manusia untuk mengerti maksud dan rencana Allah.

Dalam pembagian menurut arti, kata perjanjian memiliki makna pemakaian yang jarang digunakan yaitu dalam penggunaan dengan nama dewa (Hak. 8:33, 9:46). Mungkin artinya bahwa dewa ini telah membuat hubungan atau perjanjian dengan orang-orang.

\footnotetext{
${ }^{1}$ Gerald O'Collins,SJ dan Edward

G.Farrugia,SjKamus Teologi,Perjanjian,CovenantIkatan antara Allah dengan seluruh umat manusia yang diwakili oleh Nuh (Kej. 9:8-17) dan Abraham serta keturunannya (Kej 15:18;17:1-11). Di Sinai
}

Pelajaran dari sumber-sumber Ugaritik mungkin bisa menolong dalam pengeritian ini. Sebagai contoh para sarjana melihat adanya kaitan dalam naskah Mazmur 89 di Timur Dekat kuno di lingkup perjanjian dan bahkan Allah. Konsep tentang yang berkuasa, pujian, dan hal tahta juga disertakan. Hal ini harus diakui bahwa adanya hubungan dalam beberapa bentuk kuno puisi Timur Dekat yang sama. Tapi apakah ini merupakan hubungan langsung?

Hubungan Allah dengan umat-Nya digambarkan di sepanjang Alkitab dengan istilah 'perjanjian'. Kata ini muncul pertama kali dalam Kejadian 6:18 dan menjangkau hingga Perjanjian Baru, di mana Allah membuat perjanjian yang baru dengan umat manusia di dalam Yesus Kristus. Sehingga pemahaman inilah yang tidak terbantahkan ketika perjanjian Allah dengan manusia memiliki kontiunitas dalam sepanjang zaman.

Tujuan Allah adalah untuk memberikan janji-janji permanen yang akan menjamin sifat abadi dari hubungan perjanjian dan tidak bisa ditiadakan oleh apaapa. Dia bukan Allah yang berubah-ubah. Sebaliknya, Allah juga ingin supaya orang Israel menjadi setia kepadanya. Dia adalah Allah yang cemburu (Kel. $34: 14)^{2}$

Diawali dengan janji Allah kepada Abraham bahwa melalui keturunannya seluruh bangsa akan diberkati. Abraham digunakan sebagai contoh iman. Abraham adalah model orang

\footnotetext{
Allah mengikat perjanjian itu (Kel.20:1-17;U1.5:1-

21;Yer 11:1-8), (Yogyakarta:Penerbit

Kanisius,tt),p. 251

${ }^{2}$ Carl Reed, Theology of Pentateuch (Diktat STTII

Yogyakarta), 199
} 
yang bersandar pada Tuhan dalam iman. Seluruh hidupnya telah membuktikan bahwa ia sungguh-sungguh percaya kepada Allah,dengan iman yang mendalam seperti yang tertulis dalam Kej.15:6. Ayat-ayat ini oleh Penulis PB dan kebenaran dasar di dalamnya dikembangkan lebih lengkap. ${ }^{3}$ Penggenapan janji keturunan Abraham akan seperti debu tanah dan bintang-bintang di langit terdapat dalam Keluaran 1:7 yang menunjukkan bahwa orang-orang Israel beranak cucu dan tak terbilang jumlahnya.

Bangsa Israel yang merupakan keturunan Abraham, dalam perjalanan sejarahnya telah melewati pahit getirnya hidup dalam perbudakan di tanah Mesir. Mereka dipimpin untuk keluar dari Mesir oleh Musa, setelah terjadinya sepuluh malapetaka yang memaksa bangsa Mesir mengakui bahwa terdapat satu Allah di surga yang menguasai seluruh kejadian di dunia. Kitab Keluaran menceritakan semua kejadian tersebut. Perjanjian Abraham menjadi alasan yang kuat dari pembebasan bangsa Israel keluar dari tanah Mesir.

Pada akhirnya bangsa Israel berdiam di tanah Kanaan, negeri yang dijanjikan ${ }^{4}$ kepada Abraham. Bangsa Israel sebagai keturunan Abaraham dapat menempati tanah yang dijanjikan meskipun membutuhkan waktu yang lama untuk penggenapan dari janji tersebut. Penundaan ini bisa saja disebabkan adanya kedurhakaan orang Amori belum genap (Kejadian 15:16) atau memang Allah menginginkan bangsa Israel belum waktunya sampai waktu yang telah ditentukan Allah bahwa 400 tahun bangsa Israel akan dianiaya dan diperbudak (Kejadian 15:13), kendati anak-anak Yakub pernah pulang ke Kanaan untuk menguburkan Yakub (Kejadian 50:7-11). Dalam memahami sifat progresivitas

\footnotetext{
${ }^{3}$ Ensiklopedi Alkitab Masa Kini Jilid I (Jakarta:Yayasan Komunikasi Bina Kasih/OMF,2003), 431

${ }^{4}$ W.R.F.Browning. Kamus Alkitab (Jakarta: BPK Gunung Mulia,2008), 170
}

Perjanjian Lama, perkembangan sejarah Perjanjian lama memiliki arti penting dalam setiap peristiwanya. Ketika menelusuri wahyu Allah dalam periode-periode yang penting dalam sejarah Perjanjian Lama,maka diitemukan perjanjian yang dibuat oleh Allah kepada Abraham, Musa dan Daud.

Sasaran akhir perjanjian Allah dengan manusia ialah membawa keselamatan, bukan hanya kepada satu bangsa (Israel), tetapi kepada seluruh umat manusia.

Allah sudah menjanjikan kepada Abraham bahwa di dalam dia "semua kaum di muka bumi" akan diberkati (Kej. 12:3; $\underline{18: 18}$; Kej. 22:18; bd. Kej. 26:4). Allah menyalurkan kasih karunia perjanjian-Nya kepada bangsa Israel supaya mereka dapat menjadi "terang bagi bangsa-bangsa" (Yes. 49:6; bd. Yes. 42:6). Perjanjian ini digenapi oleh kedatangan Tuhan Yesus Kristus sebagai Penebus, ketika orang Kristen mulai menyebarkan berita Injil ke seluruh dunia (lih. Luk. 2:32; Kis. 13:46-47; Gal. 3:8$\underline{14)} .^{5}$

Dengan demikian janji tersebut diungkapkan secara berkelanjutan sampai yang menjadi sasaran utama terpenuhi. Walter C. Kaiser mengatakan," janji itu secara berkesinambungan digenapi dalam Perjanjian Lama namun menunggu penggenapan puncaknya dalam hubungan dengan dua kedatangan Mesias-Sang Hamba." 6

\footnotetext{
${ }^{5}$ http://alkitab.sabda.org/article.php?id=8403, 23 Maret 2014

${ }^{6}$ Walter C.Kaiser,Jr. Teologi Perjanjian Lama (Malang: Penerbit Gandum Mas,2004) , 337
} 
Kehadiran satu bangsa pilihan yang berawal dari perjanjian Allah dengan Abraham, dimulai juga dengan janji Allah kepada Abraham tentang keturunan yang akan menjadi pewaris Abraham dikemudian hari. Sudah barang tentu hal ini diawali dengan janji Allah kepada keturunan Hawa yang akan menjadi penyelamat (Kej. 3:15). Sehingga terjadi perkembangan pernyataan Allah secara spesifikasi dan representativ dengan hadirnya keturunan Abraham.

Ketika Tuhan menampakkan diri kepada Abraham setelah tiba di Sikhem, janji tentang keturunan diulangi kembali (Kej. 12:7). Hal itu berarti hadirnya ahli waris akan menjadi penentu bagi datangnya berkat bagi bangsa-bangsa. ${ }^{7}$ Walter $\mathrm{C}$. Kaiser dalam bukunya Teologi Perjanjian Lama mengatakan, "keturunan selalu merupakan kata benda tunggal kolektif," dalam hal ini berarti keturunan itu bisa menunjuk kepada hadirnya keturunan sebagai pemberian yang akan datang dan keturunan sebagai penerima karunia sementara dan karunia rohani dari Allah saat sekarang. ${ }^{9}$ Penulis sangat meyakini kehadiran Mesias melalui keturunan Abraham karena dasarnya adalah iman, sebagaimana yang diperbuat oleh Abraham.

Kehadiran Abraham telah mengantar kepada babak baru dengan hadirnya bangsa Israel yang kemudian memunculkan seorang pemimpin yang akan menjadi tipologi Kristus, yaitu Musa. Kelanjutan perjanjian yang dibuat oleh Allah dengan leluhur Israel, kini disebut sebagai perjanjian Allah dengan Musa. Hal itu bisa saja disebut perjanjian antara Allah dengan umat Israel, keturunan Abraham; perjanjian itu diikat Allah dengan umat Israel melalui

${ }^{7}$ Eugene H. Merrill, Tologi Pentateukh, editor: Roy B. Zuck, A Biblical Theology of the Old Testament, (Malang: Penerbit Gandum Mas, 2005), 57 ${ }^{8}$ Walter C.Kaiser,Jr. Teologi Perjanjian Lama (Malang: Penerbit Gandum Mas,2004) 122-123 ${ }^{9}$ Ibid
Musa. Sehingga perjanjian Abraham merupakan payung bagi perjanjian Musa. Sebab seseorang yang masuk dalam perjanjian Musa harus diikat dahulu dengan perjanjian Abraham. Bangsa Isarel dipilih oleh Allah dan dilepaskan dari perbudakan Mesir (Keluaran 15:4), selanjutnya status terpilih bagi bangsa Israel di dunia diungkapkan di dalam Keluaran 19:1-13. ${ }^{10}$ Hukum Tuhan diberikan kepada bangsa Israel agar bangsa Israel mampu mempertahankan perjanjian yang telah dibuat. Carl A. Reed dalam diktatnya Theology og The Pentateuch mengatakan, “ Hukum Taurat diberikan kepada bangsa Israel supaya mereka bisa mencapai rencana Allah bagi mereka, yaitu menjadi kerajaan imam dan bangsa yang kudus (Kel. 19:46). ${ }^{11}$

Namun perjanjian Musa ini (perjanjian Sinai) telah rusak karena orang Israel di padang gurun menyembah patung lembu emas (Keluaran 32:19). Kitab Hakim-Hakim menjadi saksi betapa bangsa Israel telah mengikuti keinginan sendiri daripada keinginan Tuhan. Padahal setelah Perjanjian Sinai disahkan (Keluaran 24:18),Allah memerintahkan untuk membangun Tabernakel (kemah suci) supaya kehadiran Allah dapat berdiam di tengah-tengah mereka.

Kehadiran Allah tidak akan berdiam diantara bangsa Israel sampai dosa umat ditebus dan perjanjian diperbarui. Dosa penyembahan berhala merupakan kekejian bagi Allah. Hal ini telah banyak disuarakan oleh nabi-nabi. ${ }^{12}$ Dosa ini yang menjadikan terputusnya hubungan umat dengan Allah. Inilah konsekuensi logis bagi bangsa Israel yang sudah terikat dengan janji. Mereka

\footnotetext{
${ }^{10}$ John F. Walvoord, Pedoman Lengkap Nubuat Alkitab (Bandung: Yayasan Kalam Hidup, 2003), 41

${ }^{11}$ Carl A. Reed, Diktat Theology of The Pentateuch Part 1: introduction, (Yogyakarta: STII, 2011), 11

${ }^{12}$ Ensikopedi Alkitab Masa Kini jilid I (Jakarta:

Yayasan Komunikasi Bina Kasih/OMF,2003), 182
} 
Jurnal Teologi \& Pelayanan ( Kerusso )

E-ISSN: 2714-9587

P-ISSN: 2407-554X

harus hidup dalam ketaatan kepada Allah (Kel. 23:24).

\section{HASIL DAN PEMBAHASAN}

Perjanjian Allah dengan Daud merupakan bagian inti untuk memahami rencana Allah bagi perkembangan perwujudan pemulihan keadaan Israel di tengah-tengah keterpurukan bangsa. Daud menjadi figur yang ideal bagi raja di masa eskatologis. Di masa yang akan datang janji itu dipenuhi, diperbaharui dan diperluas. Melalui nabi Natan janji diberikan kepada Daud (2 Samuel 7:12-17). Kata perjanjian memang tidak ada dalam ayat tersebut tetapi konsepnya ada. ${ }^{13}$ hal tentang konsep janji akan dijelaskan panjang lebar dalam bagian penjelasan istilah.

Dalam bentuk yang lebih awal Alkitab Ibrani memperlakukan 1 \& 2 Samuel sebagai satu kitab. Begitu pula dengan Kitab 1 \& 2 Raja-raja. Para penerjemah LXX menggabungkan Kitab Samuel dan Raja-raja sebagai Kitab-kitab Kerajaan (Bibloi Basileiwn), yang lalu dibagi menjadi 4 kitab kerajaan (1 Samuel = 1 Kerajaan, 2 Samuel = 2 Kerajaan, 1 Rajaraja $=3$ Kerajaan, 2 Raja-raja $=4$ Kerajaan). Terjemahan Latin Vulgata yang semula mengikuti LXX kemudian mengganti istilah Kitab Kerajaan (Libri Regnwrum) dengan pembagian seperti di Alkitab Ibrani (Kitab Samuel dan Kitab Raja-raja). Baru pada edisi Bomberg tahun 1517 Alkitab Ibrani membagi masing-masing kitab itu menjadi dua bagian. ${ }^{14}$

Kitab 1 dan 2 Samuel (selanjutnya oleh penulis disebut kitab Samuel) ditulis sebagai langkah penelusuran jejak perjanjian yang pernah dibuat Allah dengan bangsa Israel melalui bentuk pemerintahan kerajaan. Kitab Samuel juga ditulis dengan tujuan tertentu. Kitab ini ingin mengajarkan

\footnotetext{
${ }^{13}$ Ibid

${ }^{14}$ Gleason L. Archer, A Survey of Old Testament Introduction, rev. ed., 311.
}

bahwa kerajaan merupakan anugerah dari Allah. ${ }^{15}$

Aspek anugerah dalam penetapan perjanjian dengan Daud diperjelas melalui beberapa cara. Pertama, cara Daud bersikap setelah ia diurapi sebagai raja. Sikap Daud terhadap Saul turut mempertegas fakta bahwa pengangkatan dirinya sebagai raja merupakan murni inisiatif Allah. Ia beberapa kali membiarkan Saul hidup (1Sam 24, 26), sehingga tidak akan orang yang menganggap dia telah merebut kekuasaan Saul. Daud tidak mau menjamah orang yang diurapi TUHAN (1Sam 24:7). Ia membiarkan TUHAN sendiri yang akan menghukum Saul (1Sam 26:10-11). Bahkan ketika seorang Amalek melaporkan bagaimana ia telah membunuh Saul atas permintaan Saul sendiri, Daud memerintahkan tentaranya untuk membunuh orang itu, karena orang itu telah menjamah orang yang diurapi oleh TUHAN (2 Sam 1:14, 16).

Kedua, dosa-dosa Daud. Perjanjian yang telah dibuat TUHAN dengan Daud tidak dapat ditiadakan oleh kelemahan dan kegagalan Daud. Kitab 2 Samuel mencatat beberapa dosa Daud yang sangat serius, yaitu merampas Betsyeba dari tangan Uria (2 Sam 11:1-12:31) dan menghitung rakyat (2 Sam 24:1-17). Semua kesalahan ini bisa saja membawa perjanjian ke dalam bahaya, namun Allah selalu menyediakan sarana pengampunan dan restorasi. Kitab Samuel bahkan diakhiri kegagalan Daud (2 Sam 24:1-17) dan kesetiaan Allah terhadap umat-Nya (2 Sam 24:18-25).

Yang paling penting untuk diperhatikan dalam kitab Samuel ini adalah adanya desakan orang Israel untuk memiliki raja dipandang TUHAN sebagai sesuatu yang salah (1Sam 8:7). Kesalahan dalam tindakan ini terletak pada ketidakmauan bangsa Israel bergantung pada Allah dalam

\footnotetext{
${ }^{15}$ Expositor's Bible Commentary, electronic edition.
} 
menanti seorang penyelamat seperti pada jaman hakim-hakim dahulu. Mereka menginginkan sebuah jabatan pemimpin yang permanen seperti bangsa-bangsa lain (1Sam 8:5, 20), yang akan memimpin dan membebaskan mereka dari tangan musuh (1 Sam 8:20). Sistem kerajaan tidak boleh menggantikan pemerintahan teokrasi. Allah tetap yang mengatur segala sesuatu (1Sam 8:10-18).

Bentuk pemerintahan kerajaan sendiri tidaklah salah. Allah bahkan memilih Daud dan berjanji mengokohkan kerajaannya (2 Sam 7:13-14). Salah satu janji Allah kepada Abraham adalah bahwa keturunannya akan menjadi raja-raja dunia (Kej. 17:6). Kehadiran raja di tengah bangsa Israel juga sudah diantisipasi oleh TUHAN (Ul. 17:1420).

Seorang raja diperlukan untuk memimpin bangsa Israel menaati perjanjian (bdk. Hak 21:25). Kitab ini ingin mengajarkan bahwa institusi kerajaan sudah berada dalam rencana Allah (Ul 17:14-20) dan Allah bahkan memakai itu untuk mendirikan sebuah dinasti bagi diri-Nya sendiri melalui Daud. Dengan kata lain, kitab ini menjelaskan dasar perjanjian ilahi yang dibuat TUHAN dengan keturunanDaud (2 Sam 7:14-20). ${ }^{16}$

Dalam konteks 2 Samuel 7, setelah Daud mengalami kesuksesan dalam kerajaannya, ia bermaksud mendirikan Bait Allah supaya umat Israel dapat menyembah Allah disana secara permanen dan layak. Tetapi melalui nabi Natan, yang dipikirkan Daud tidaklah seperti yang diinginkan Allah. Melalui keinginan Daud inilah, ditemukan ide Allah yang besar yaitu rencana untuk mengokohkan kerajaannya selama-lamanya. Ide untuk mengokohkan kerajaannya diawali janji tentang pemberian keturunan Daud. Nabi Natan menyampaikan firman Tuhan kepada Daud dalam 2 Samuel 7:12-13: “. . . Aku akan membangkitkan keturunanmu yang

\footnotetext{
${ }^{16}$ Andrew Hill \& John Walton, A Survey of the Old Testament, 210.
}

kemudian, anak kandungmu, dan Aku akan mengokohkan kerajaannya. Dialah yang akan mendirikan rumah bagi nama-Ku dan Aku akan mengokohkan takhta kerajaannya untuk selama-lamanya."

Sebagaimana perjanjian dengan para leluhur Israel, perjanjian dengan Daud ini didasarkan pada anugerah Allah semata sebab munculnya bukan karena kekuatan dan kebesaran Daud. Allah mengangkat Daud dari pekerjaan sebagai gembala ternak untuk menjadi penggembala Israel, umat Tuhan (Mazmur 89:20). Sikap Allah yang mendisiplin keturunan Daud serta komitmen mengokohkan kerajaannya tertulis dengan jelas dalam Mazmur 89:3135.

Perjanjian dengan Daud merupakan tindak lanjut dari perjanjian-perjanjian sebelumnya, di mana aspek kesetiaan Allah terhadap bangsa Israel semakin dinyatakan. Sehingga bisa jadi dalam hal ini sikap providensia perjanjian ini merupakan pengulangan dari perjanjian di Sinai.

\section{KESIMPULAN}

Hubungan Allah dengan umat-Nya digambarkan di sepanjang Alkitab dengan istilah "perjanjian." Kata ini muncul pertama kali dalam Kejadian 6:18 dan menjangkau hingga Perjanjian Baru, di mana Allah membuat perjanjian yang baru dengan umat manusia di dalam Yesus Kristus. Dengan memahami perjanjian Allah dengan para bapa leluhur (Abraham, Ishak, dan Yakub), nama Allah yang khusus dipakai dalam perjanjian di Alkitab adalah Yahweh (diterjemahkan "TUHAN").

Tema tentang perjanjian atau 'janji' keselamatan bagi manusia menjadi tema sentral Perjanjian Lama. Dalam kaitan ini maka Perjanjiian Daud dalam 2 Samuel 7 dan perkembangannya dalam kitab Mazmur 89 menjadi sangat penting bagi arah 
penggenapan seluruh perjanjian dalam perjanjian Lama. Sebagaimana rumusan masalah yang telah dituliskan yaitu "dalam hal apa kesinambungan perjanjian Daud berlaku kekal? Serta mengapa seolah-olah Perjanjian itu dibatalkan dalam Mazmur 89?"Maka dari hasil pengamatan dan penulisan disertasi ini, penulis menemukan beberapa hal tentang kesinambungan perjanjian Daud berlaku kekal. Pertama, berkenaan dengan latar belakang perjanjian Daud yang bersangkut paut dengan perjanjian Abraham. Perjanjian dengan Abraham adalah satu langkah utama dalam wahyu illahi yang menyatakan bahwa Allah telah memilih Abraham dan keturunannya untuk menggenapkan maksud-Nya untuk menyatakan diri-Nya sendiri kepada dunia dan membawa keselamatan bagi umat manusia. Dalam penggenapan perjanjian berkat tersebut, tidak ada sesuatu yang mengindikasikan bahwa Abraham memiliki keunggulan moral dibandingkan dengan bangsa-bangsa lain sehingga layak untuk dipakai Allah. Namun dalam kedaulatanNya, Allah memilih Abraham dan dalam pilihan-Nya Allah menuntut iman dari Abraham. Kebenaran yang tidak dapat dipisahkan dalam perjanjian berkat bagi Abraham adalah berkat yang selalu disiapkan bagi setiap orang yang beriman dan mau bertindak dalam rencana dan kehendak Allah.

Namun dalam kitab 2 Samuel 7 latar belakang berkat nasional dari perjanjian Abraham sanagatlah dekat dengan konteks pembahasan. Israel adalah benih dari Abraham. Panggilan Abraham merupakan langkah awal yang dikerjakan Tuhan untuk menggenapi maksud dan rencana-Nya menyelamatkan umat-Nya.

Dari Abraham inilah Tuhan menghendaki munculnya suatu keluarga yang taat dan hidup benar di hadapan-Nya,suatu bangsa pilihan yang memiliki kehidupan yang berbeda dari bangsa-bangsa lain di dunia. Munculnya keluarga Yakub atau
Israel telah melahirkan sebauh bangsa pilihan di dunia. Tuntutan kesetiaan bangsa Israel terhadap perintah Tuhan menjadi taruhannya. Sampai pada akhirnya bangsa Israel harus diuji untuk menemukan jati dirinya di hadapan Tuhan.

Tindakan yang sesuai dengan perjanjian menuntut adanya kesetiaan. Mematahkan janji adalah suatu pelanggaran terhadap Tuhan. Berarti pula: mendatangkan kutuk sesuai dengan yang telah diucapkan di dalam pengukuhan perjanjian. Untuk menguji ketaatan dan keputusan bebas manusia dalam mengikuti penciptanya, Allah menempatkan pohon pengetahuan yang baik dan yang jahat di Taman Eden dengan satu peraturan bahwa Adam dan Hawa tidak boleh memakan buahnya. Dosa Adam dan Hawa dilakukan atas kehendak diri mereka sendiri. Segala dosa disebabkan oleh pilihan kehendak manusia.

Kegagalan bangsa Israel untuk taat disebabkan tuntutan untuk menghadirkan seorang raja yang mengerti kebutuhannya. Perubahan sistem dari sistem Teokrasi menjanji sistem Monarkhi dalam pemerintahan Israel menjadikan hadirnya kerajaan Daud.

Walaupun demikian, kegagalan manusia untuk menaati peraturan membuktikan lemahnya manusia untuk memegang janji Allah bagi keberlangsungan berkatNya. Janji ini adalah perluasan dari janji yang diberikan dalam Kej 3:15, yang menubuatkan kekalahan Iblis melalui keturunan Hawa. Dengan penyataan janji Allah untuk memberkati seluruh makhluk ciptaan, maka tema kesatuan antara berkat dan janji dalam sepanjang zaman pra bapak leluhur sampai zaman raja Daud mewarnai topik-topik peristiwa sejarah umat manusia.

Gagasan ini muncul berdasarkan adanya ada satu aspek dari perjanjian Allah dengan Daud yang tidak bersyarat -- yaitu bahwa kerajaan Daud pada akhirnya akan ditetapkan untuk kekal. Sekalipun istilah "perjanjian" tidak dipakai dalam 2 Sam 7:129, jelaslah bahwa Allah sedang mengikat 
perjanjian dengan Daud. Janji ini bahwa takhta umat Allah akan selama-lamanya ditegakkan oleh keturunan Daud merupakan janji yang diberikan Allah kepada Daud. Kedua prinsip sama yang berlaku dalam perjanjian lainnya di Perjanjian Lama juga tampak di sini: Allah sendiri yang menentukan janji-janji dan kewajiban dari perjanjian-Nya, sedangkan manusia diharapkan menerimanya dengan iman yang taat. Sasaran akhir perjanjian Allah dengan manusia ialah membawa keselamatan, bukan hanya kepada satu bangsa (Israel), tetapi kepada seluruh umat manusia.

\section{DAFTAR PUSTAKA}

[1] Archer, Jr., Gleason. A Survey of Old Testament (Chicago: The Moody Bible Institure)

[2] Baker, David L. Mari Mengenal Perjanjian Lama (Jakarta: BPK Gunung Mulia, 1997)

[3] Barth, Ch. Theologia Perjanjian Lama (Jakarta: BPK Gunung Mulia, 1988)

[4] Barton, John. Reading in The Old Testament: Method in Biblical Study (Philadelphia: Westminster, 1984)

[5] Brill, J. Wesley. Dasar Yang Teguh (Bandung: Yayasan Kalam Hidup, 2004)

[6] Brown, Francis (Ed). The New BrownDriver-Gesenius Hebrew and English Lexicon (Massachusetts: Hendrickson Publishers)

[7] Bruce, F.F. The New Testament Develeopment of Old Testament Themes (Grand Rapids: Mich., 1973)

[8] Childs, Brevard S. Biblical Theology in Crisis (Philadelphia: Westminster, 1970)
[9] Douglas, J.D. (Penulis/Editor) Ensiklopedia Alkitab Masa Kini (Jakarta : Yayasan Komunikasi Bina Kasih, 1994)

[10] Drane, John. Memahami Perjanjian Lama I (Jakarta: Yayasan Persekutuan Pembaca Alkitab, 2002)

[11] Dumbrell, W.J. Covenant and Creation (Nashville: Thomas Nelson, 1984)

[12] Dyrness, William. Tema-Tema dalam Teologi Perjanjian Lama (Malang: Penerbit Gandum Mas, 1979)

[13] Faot, A., Octavianus, J., \& Juanda, J. (2017). Kematian Bukan Akhir Dari Segalanya. Journal Kerusso, 2(2), 15-30.

[14] Gultom, Parlaungan. Diktat Teologi Kitab-Kitab Sejarah Perjanjian Lama (Yogyakarta: STTII Yogyakarta, 2012)

[15] Hadiwijono, Harun. Iman Kristen (Jakarta: BPK Gunung Mulia, 2007)

[16] Hasel, Gerhard F. Teologi Perjanjian Lama (Malang: Penerbit Gandum Mas, 2006)

[17] Hill, Andrew. Survei Perjanjian Lama (Malang: Yayasan Penerbit Gandum Mas, 1991)

[18] Hill. Andrew E. \& Walton John H. Survei Perjanjian Lama (Malang: Gandum Mas, 1996)

[19] Howard, David M. Jr., Kitab-Kitab Sejarah (Malang: Gandum Mas, 2009)

[20] Karman, Yongky. Teologi Perjanjian Lama, (Jakarta: BPK Gunung Mulia, 2009)

[21] Keiser, Walter C. Jr (Malang: Penerbit Gandum Mas, 2004)

[22] Lasor, W.S. Pengantar Perjanjian Lama 1 (Jakarta: BPK Gunung Mulia, 2010) 
[23] Lasor, W.S. Pengantar Perjanjian Lama 2 (Jakarta: BPK Gunung Mulia, 2010)

[24] Ludji, Barnabas. Tafsiran Beberapa Teks Perjanjian Lama, (Bandung: Bina Media Informasi, 2009)

[25] Marantika, Chris. Kristologi (Yogyakarta: Iman Press, 2008)

[26] Martus A. Maleachi, Karakteristik dan Berbagai Genre dalam Kitab Mazmur.

Veritas 13/1 (April 2012)

[27] Mawene, Marthinus Theodorus. Perjanjian Lama dan Teologi Kontekstual, (Jakarta: BPK Gunung Mulia, 2008)

[28] Michaeli, Frank (Penulis/Editor). Bagaimana Memahami Perjanjian Lama (Bandung: BPK Gunung Mulia, Jakarta, 1995)

[29] Murray, J. penerjemah: Harus Hadiwijono, Ensiklopedi Alkitab Masa Kini Jilid 1 (Jakarta: Yayasan Komunikasi Bina Kasih/OMF, 1994)

[30] Poerwadarminta, W.J.S. Kamus Umum Bahasa Indonesia (Jakarta: PN Balai Pustaka, 1983)

[31] Saparman, S.T.M, Belajar Alkitab, (Yogyakarta: Iman Press, 2007)

[32] Sihotang, Samin H. Kasus-Kasus dalam Perjanjian Lama (Bandung: Yayasan Kalam Hidup, 2005)

[33] Singgih, Emanuel Gerrit. Dua Konteks, (Jakarta: BPK Gunung Mulia, 2009)

[34] Tremper Longman III, Bagaimana Menganalisa Kitab Mazmur ,(Malang:Literatur SAAT,2007)
[35] Walton, John H. Mazmur: Sebuah Kantata Tentang Perjanjian Daud. Jurnal Teologi Penginjilan Masyarakat 34 (1991)

[36] Walvoord, John F. Yesus Kristus Tuhan Kita (Suarabaya: Yakin, tt)

[37] Walvoord, John. F. \& Roy B. Zuck (Editor). The Bible Knowledge Commenetary (Victor Books, 1985)

[38] Wroght, Christopher. Hidup Sebagai Umat Allah; Etika Perjanjian Lama (Jakarta : Yayasan Kalam Hidup, 1961)

[39] Zimmerli, W. An Outline of Old Tetsament Theology (Stuttgart: W. Kohlhammer, 1972

[40] Zuck, Roy B. (Editor). A Biblical Theology of The Old Testament (Malang: Penerbit Gandum Mas. 2005) 